\title{
ORGANIZATION OF CURRICULUM AND EDUCATION IN TECHNICAL TRAINING
}

\author{
Gyula BAGYINSZKI ${ }^{1}$, Enikő BITAY ${ }^{2}$ \\ ${ }^{1}$ Óbuda University, Bánki Donát Mechanical and Safety Engineering, Budapest, Hungary, \\ bagyinszki.gyula@bgk.uni-obuda.hu \\ ${ }^{2}$ Sapientia Hungarian University of Transylvania, Faculty of Technical and Human Sciences, Târgu Mures,, \\ Romania, ebitay@ms.sapientia.ro
}

\begin{abstract}
Proper management of the realization of the general and special training objectives of technical higher education makes it necessary to organize the curriculum and the educational process according to didactic, methodological aspects. Selection of curriculum elements with deductive and inductive approach and their horizontal and vertical arrangement are required. In addition, the curriculum concentration of a given subject, i.e. its connection to other subjects, must be taken into account. This article intends to add to this by raising some points.
\end{abstract}

Keywords: curriculum, deductive, inductive, horizontal, vertical.

\section{Organizing the curriculum}

In the interest of motivating towards the different technical domains and specialty fields it is useful if - within the framework of the fundamental subjects connected to these fields - the characteristic problems are introduced in the curricular conception from the very beginning. These are served well by the so called associative, or unified curricula. Their essence is presented in Figure 1. By comparing them to the two basic versions: the deductive and the inductive (which generalizes based on the specific) curricula. [1].

The deductive approach therefore consists in getting from known true statements to new true statements by means of deduction, while the inductive learning consists in formulating generally valid statements based on specific observations. Regarding the knowledge obtained by the latter method, it cannot be considered to be certainly and absolutely true, only probably (hypothetically) true, since the generalization is based on a finite (low) number of observations. The inductive approach is a complex process; it has the following essential elements: searching for analogies, induction of rules, establishing of counter-examples, proof. An example for the inductive method would be the teaching of the crystallization process of pure metals by establishing and analyzing the cooling graphs and by confirmation of the Gibbs phase law. An example of the deductive method would be the teaching of the crystallization process of pure metals based on a given cooling graph and the Gibbs phase law. Further examples of the deductive method can be seen in Figure 2. [2].

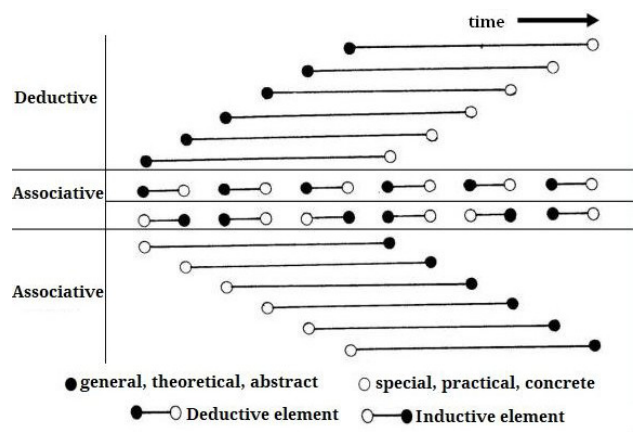

Figure 1. Curriculum structures 
The system of criteria for the teaching of the structures mentioned in Figure 2. is az follows:

- basic principles, fundamental notions

- technological parameters and calculations

- procedures and equipment

- applicability, advantages, disadvantages, economic viability

- management of quality, necessary and opportune material analysis

- safety technique, environmental protection

- country-specific considerations, international comparison

The selection and organizing of the taught contents becomes more and more an activity that needs expertise and therefore it is a task for every teacher and every teaching collective, with the appreciation of different groups of factors (Figure 3.) [3].

The two categories of additive teaching aims from the first group of factors are the scientific worldview and the human competences that provide the necessary stability for the organizing of the teaching - learning activity and at the same time they allow for a flexible space for any changes that can occur as a means to prove the progressive and adaptive nature of the organizing of teaching. These aims are never unidirectional or deterministic; they also contain the regulative effect of feedback coming from both the results of the teaching and the qualitative control processes.

\begin{tabular}{|c|c|c|c|}
\hline \multirow{5}{*}{ Steps } & $\begin{array}{c}\text { I. } \\
\text { Refreshing of previously } \\
\text { learned information, or- } \\
\text { ganizing them into a new } \\
\text { system (e.g. a recapitulation } \\
\text { of the mechanisms of shape- } \\
\text { shifting) }\end{array}$ & $\begin{array}{c}\text { II. } \\
\text { Establishing of new notions, } \\
\text { basic principles. Teaching } \\
\text { of the fundamentals of tech- } \\
\text { nologies (e.g. the processing } \\
\text { of the principles of plas- } \\
\text { tic-forming) }\end{array}$ & $\begin{array}{c}\text { Applying of new knowledge, } \\
\text { teaching of unique manu- } \\
\text { facturing technologies (e.g. } \\
\text { teaching of rolling, smithing } \\
\text { technologies) }\end{array}$ \\
\hline Methods & $\begin{array}{c}\text { Investigating the level of } \\
\text { previous knowledge by } \\
\text { means of questions. Com- } \\
\text { pleting previous knowledge } \\
\text { by discussion and solving } \\
\text { problems. }\end{array}$ & $\begin{array}{c}\text { Explanations and illustra- } \\
\text { tion by the teacher, in some } \\
\text { cases visiting the factories } \\
\text { for the processing of new } \\
\text { information. Teaching based } \\
\text { on problems in the phase of } \\
\text { applications. }\end{array}$ & $\begin{array}{c}\text { Explanations and illus- } \\
\text { trations by the teacher, } \\
\text { processing of informations } \\
\text { based on a directed series of } \\
\text { questions from the manual. } \\
\text { Autonomous applications: } \\
\text { solving of problems. }\end{array}$ \\
\hline Results & $\begin{array}{c}\text { New competences in apply- } \\
\text { ing fundamental knowledge. }\end{array}$ & $\begin{array}{c}\text { Learning of new notions, } \\
\text { correlations, principles and } \\
\text { structures. }\end{array}$ & $\begin{array}{c}\text { Experience in applying } \\
\text { knowledge in technologies. }\end{array}$ \\
\hline
\end{tabular}

Figure 2. Deductive processing of curricula

TECHNICAL CULTURE

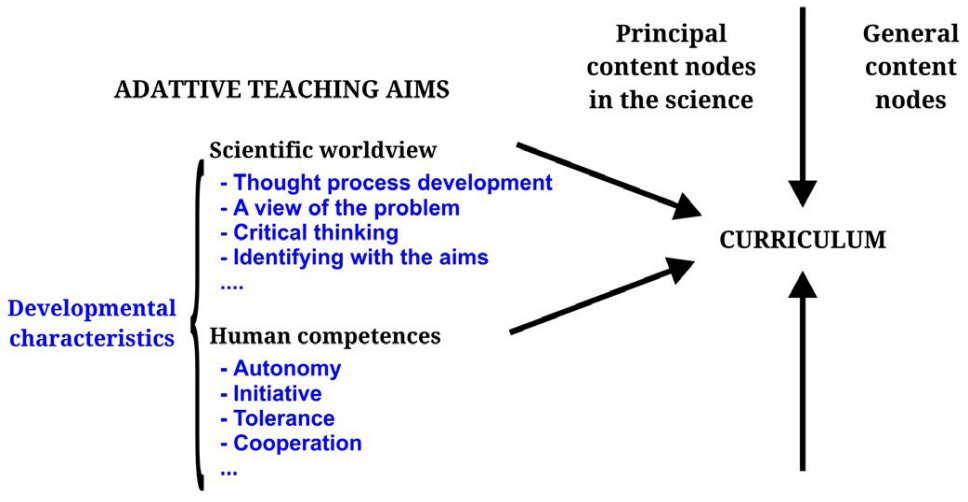

A perception of teaching - learning

MOTIVATION - ACTIVATION - DIFFERENTIATION

Figure 3. Factors that influence curriculum selection 
The second group of factors consists of the notion of a technical culture that is the sum of all relations towards specialty sciences and all material, social and spiritual objectivations in other words, always a sum of things (values) and activities (original creation, practical use, reshaping re-creation, interiorization etc.).

The third group of factors is the perception of teaching - learning, the expression of which in the curriculum makes it possible for students with very different capabilities, motivations and fields of interest to learn in a way that matches both expectations and their own interest [3].

\section{Organizing of teaching}

The curriculum chosen based on principles has to be organized in categories according to well defined criteria; this is a pre-condition for contouring its main sections which later will form the basis of the teaching - learning process. Therefore the globally assigned contents of culture have to be arranged accordingly. This arrangement can be approached from two directions: a horizontal one and a vertical one.

The vertical approach aims at a realization of the sequentiality given by the very build of the curriculum, this direction is strongly connected with the educational system and the system of teaching itself [4]

The horizontal approach poses the question of the specific thematic units that can contain during the process of teaching the different interconnected blocks of the curriculum. The horizontal arrangement is strongly connected with the selection of the curriculum, the structure of which is represented in Figure 4.
The subject and its curriculum are not some reduced version or copy of a science but a means of preparing the students - with scientific exigency and also practical effectiveness - to their future careers.

A modern curriculum is not a system of isolated subjects, but one that aims for a structure of scientific modules, that is, higher and inter-related units, scientific modules in which the contained subjects still keep their relative autonomy.

The teaching of the different themes within any given subject has to happen according to the inner logic of the entire unit and that requires the collaboration of the teachers of different specialty fields [3].

In the construction of a curriculum an important role must be attributed to the curricular concentration, that is to say that the inter-relations of different subjects have to be mapped out precisely in order to know when and how extensively those specific informations will be taught, that are necessary for processing new knowledge but are taught as part of different subjects.

This is necessary in order to build on pre-existing knowledge and thus avoid futile (and time consuming) repetitions and also to include the absolutely necessary parts [5] ] of hitherto unknown material in the curriculum of the given subject. In Figure 5. we represented the content abstracts for the curricular concentration of two basic subjects.

\section{Conclusions}

The above viewpoints and the examples presented can serve as a sample for organizing technical education and its curriculum while not ignoring the fact that the properly weighted presentation

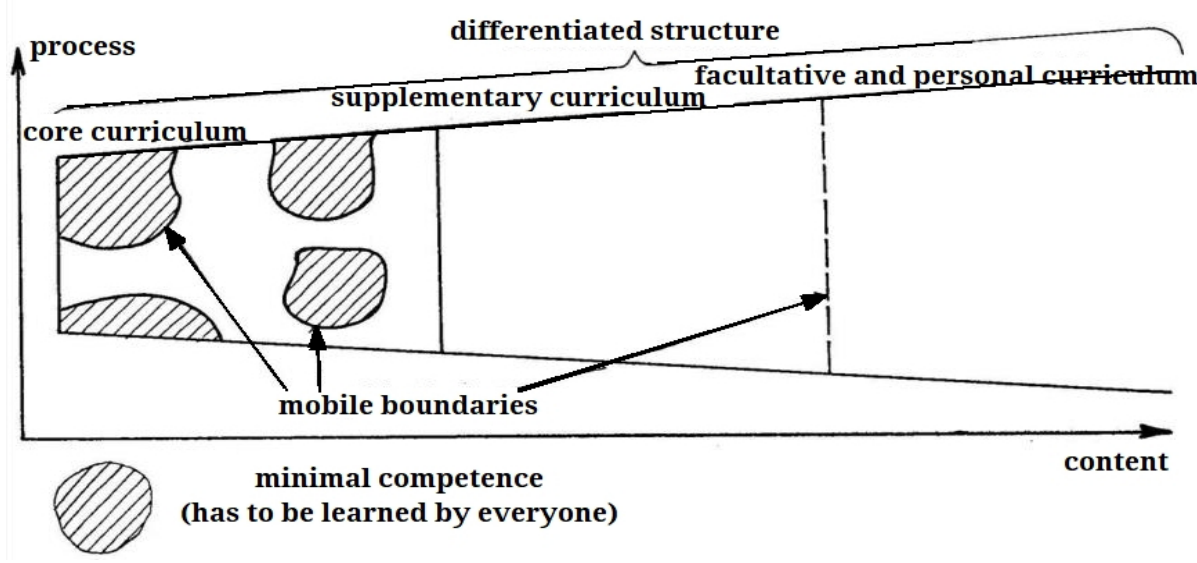

Figure 4. Curriculum structure 


\begin{tabular}{|c|c|c|c|}
\hline & MATERIAL SCIENCE & $\begin{array}{c}\text { MATERIAL } \\
\text { TECHNOLOGIES }\end{array}$ & \\
\hline \multirow{2}{*}{$\begin{array}{l}\text { MATHEMATICS Basics of } \\
\text { vector algebra, analytic } \\
\text { geometry of straight line } \\
\text { and plane, matrix calculus, } \\
\text { tensor algebra, differential } \\
\text { equations and its applica- } \\
\text { tions, function analysis }\end{array}$} & $\begin{array}{l}\text { Material structure, mac- } \\
\text { ro-, micro-, crystal- and } \\
\text { atomic structure. Material } \\
\text { structure analysis: visual, } \\
\text { non-destructive, micro- } \\
\text { scopic and electron-micro- } \\
\text { scopic }\end{array}$ & $\begin{array}{l}\text { Production of materials, } \\
\text { processing of bio-materi- } \\
\text { als, manufacturing of plas- } \\
\text { tic, metallurgy, ceramics } \\
\text { production }\end{array}$ & \multirow{2}{*}{$\begin{array}{c}\text { MECHANICS } \\
\text { Tension states, shape shift- } \\
\text { ing states, shape shifting } \\
\text { energies, equivalent ten- } \\
\text { sion, measuring to rigidity, } \\
\text { measuring to solidity }\end{array}$} \\
\hline & $\begin{array}{c}\text { selection of materials: } \\
\text { bio-materials, synthetics, } \\
\text { metals, ceramics, com- } \\
\text { posites }\end{array}$ & $\begin{array}{l}\text { shaping technologies: } \\
\text { casting, powder-forging, } \\
\text { production of sintered } \\
\text { pottery, shaping, machin- } \\
\text { ing, cutting }\end{array}$ & \\
\hline \multirow{2}{*}{$\begin{array}{l}\text { ENGINEERING PHYSICS } \\
\text { Modeling, statistical view, } \\
\text { atomic structure of ma- } \\
\text { terials, free electron gas } \\
\text { model, solid-state physics, } \\
\text { thermodynamics, elec- } \\
\text { tricity, magnetics, optics, } \\
\text { acoustics }\end{array}$} & $\begin{array}{l}\text { Characteristics of materi- } \\
\text { als: Mechanical, thermal, } \\
\text { electric, magnetic, optical, } \\
\text { acoustic, tensile testing, } \\
\text { hardness measuring. } \\
\text { Analysis of physical char- } \\
\text { acteristics } \\
\end{array}$ & $\begin{array}{l}\text { Joining technologies: } \\
\text { welding, soldering, adhe- } \\
\text { sive bonding, mechanical } \\
\text { bonding }\end{array}$ & \multirow{2}{*}{$\begin{array}{c}\text { MACHINE PARTS } \\
\text { Projection graphics, work- } \\
\text { shop design, con-struction } \\
\text { engineering and material } \\
\text { selection, forming of weld- } \\
\text { ed structures, bonding } \\
\text { elements and their appli- } \\
\text { cations }\end{array}$} \\
\hline & $\begin{array}{l}\text { Material workability by } \\
\text { casting, sintering, shap- } \\
\text { ing, machining, cutting, } \\
\text { joining, surface treatment. } \\
\text { Technological experiments }\end{array}$ & $\begin{array}{l}\text { Technologies that change } \\
\text { the structure of materials: } \\
\text { Altering monolitic materi- } \\
\text { als (foaming, felting, man- } \\
\text { ufacturing of composites, } \\
\text { thermal treatment, surface } \\
\text { treatment) }\end{array}$ & \\
\hline $\begin{array}{l}\text { TECHNICAL CHEMISTRY } \\
\text { Organic and inorganic } \\
\text { chemistry, chemical bonds, } \\
\text { counterweights, reactions } \\
\text { and equations }\end{array}$ & $\begin{array}{l}\text { Damage resistance of } \\
\text { materials: resistance to } \\
\text { gliding, fatigue, breaking, } \\
\text { abrasion, corrosion, ther- } \\
\text { mal and biological dam- } \\
\text { age. Resistance to aging }\end{array}$ & $\begin{array}{l}\text { information resources and } \\
\text { methods of technological } \\
\text { planning }\end{array}$ & $\begin{array}{l}\text { GENERAL MECHANICS } \\
\text { Physical quantities and } \\
\text { measuring units, physical } \\
\text { and empirical laws, mod- } \\
\text { els, basic measurements in } \\
\text { engineering }\end{array}$ \\
\hline $\begin{array}{l}\text { BIOLOGY } \\
\text { Cellular biology, histology, } \\
\text { organology, morphology }\end{array}$ & $\begin{array}{l}\text { Viewpoints of material } \\
\text { selection: engineering, } \\
\text { safety, standards, qualities, } \\
\text { economy- ecology-related }\end{array}$ & $\begin{array}{c}\text { Mechanizing, robotics and } \\
\text { automation in technolo- } \\
\text { gies }\end{array}$ & $\begin{array}{c}\text { INFORMATICS } \\
\text { Data processing, data- } \\
\text { bases, engineering algo- } \\
\text { rhythms }\end{array}$ \\
\hline
\end{tabular}

Figure 5. Content extract of curricular concentration for the subjects of material science and material technologies

of each subject needs a thorough background knowledge and an ability to organize it. The aim of this present article is to give some „motivation” to that through a series of intriguing thoughts.

\section{References}

[1] Lévai Z.: A mérnökképzés algoritmusa és analógiái. Felsőoktatási Szemle, 1988/5. 257-261.

[2] Simon Béláné: Mérnökpedagógiai eljárások az Anyag- és gyártásismeret tanítás-tanulásához. BMF Bánki Donát Gépészmérnöki Főiskolai Kar, Budapest, 2002.
[3] Báthory Z.: Tanulás és tanítás. Tankönyvkiadó, Budapest, 1987.

[4] Nagy S.: Az oktatáselmélet alapkérdései. Tankönyvkiadó, Budapest, 1988.

[5] Bitay E., Bagyinszki Gy.: A müszaki anyagtudomány gyakorlatorientált oktatási struktúrája. In: Fiatal műszakiak tudományos ülésszaka XVI., Kolozsvár/Cluj, Románia, Műszaki Tudományos Füzetek 2011. 47-58.

https://eda.eme.ro/handle/10598/14000 